\title{
HUKUMAN MATI DI INDONESIA MENURUT PERSPEKTIF ALKITAB DAN RELEVANSINYA BAGI PENEGAK HUKUM
}

\author{
Morris Phillips Takaliuang \\ Institut Injil Indonesia \\ Email: takaliuangmorris@gmail.com
}

\begin{abstract}
Provisions and implementation of the death penalty, is a serious and very severe law for perpetrators who are considered to have committed serious and serious violations before the law. The Indonesian state still holds and carries out such a death sentence, as regulated in the Criminal Code. There are three stages in the Bible regarding the provisions and execution of the death penalty: (1) The death penalty applies to people who sin directly to God, such as worshiping idols, turning to the spirits of the dead, chanting the name of God carelessly and not keeping the Sabbath day holy, (2) The death penalty applies to people who commit sins against others such as killing and all the acts of adultery, and (3) The provisions and execution of the death penalty are null and void for anyone who is in faith and obedience to Christ. The task as a Christian and church law enforcer is to bring sinners to believe and be in fellowship with Christ. For "criminals" who deserve to be sentenced to death, according to the Criminal Code, it is recommended that they be sentenced to life in retribution for violations. In this way, "criminals" are given the opportunity to be rehabilitated and reconstructed by Christ and His church, through Faith in Christ and His atonement work. So the point is that, the provisions and implementation of the death penalty must be canceled and replaced with life sentences. In such a sentence, "prisoners" only need to trust and obey Christ for the rest of their lives. This is called the Law of God's Grace.
\end{abstract}

Keywords: Capital punishment, Bible perspective, Christianity

\begin{abstract}
ABSTRAK: Ketentuan dan pelaksanaan hukuman mati, merupakan hukum yang serius dan sangat berat bagi para pelaku yang dianggap melakukan pelanggaran-pelanggaran serius dan berat di mata hukum. Negara Indonesia masih memegang dan melaksanakan hukuman mati seperti itu, sebagaimana diatur dalam Kitab Undang-Undang Hukum Pidana (KUHP). Di dalam Alkitab terdapat tiga tahapan tentang ketentuan dan pelaksanaan hukuman mati: (1) Hukuman mati diberlakukan kepada orang yang berdosa langsung kepada Allah, seperti menyembah berhala, berpaling kepada arwah orang mati, menyebut nama Tuhan dengan sembarangan dan tidak menguduskan hari sabat, (2) Hukuman mati diberlakukan bagi orang yang melakukan dosa terhadap sesama seperti membunuh dan semua perbuatan zinah, dan (3) Ketentuan dan pelaksanaan hukuman mati batal dan tidak berlaku lagi bagi siapapun yang berada di dalam iman dan ketaatan kepada Kristus. Tugas sebagai penegak hukum Kristen dan gereja adalah membawa orang-orang berdosa supaya percaya dan berada di dalam persekutuan dengan Kristus. Bagi "para penjahat" yang patut dihukum mati, sesuai dengan KUHP, disarankan supaya dihukum seumur hidup saja sebagai retribusi atas pelanggaran yang dilakukan. Dengan cara demikian, "para pelaku kriminal" diberi kesempatan untuk direhabilitasi dan direkonstruksi oleh Kristus dan gereja-Nya, melalui Iman kepada Kristus dan karya pendamaian-Nya. Jadi intinya adalah bahwa, ketentuan dan pelaksanaan hukuman mati harus batal dan diganti dengan hukuman seumur hidup. Dalam status hukuman seperti itu, "para narapidana" hanya perlu percaya dan taat kepada Kristus selama sisa hidup yang masih ada. Inilah namanya Hukum Kasih Karunia Allah.
\end{abstract}

Kata Kunci: Hukuman mati, perspektif Alkitab, Kristen

\section{PENDAHULUAN}

Kontroversi mengenai ketentuan dan pelaksanaan hukuman mati dan dampaknya, sudah berlangsung lama dalam sejarah kemanusiaan, tidak terkecuali di Indonesia. Terdapat beberapa alasan, banyak orang menyetujui dan menolak adanya hukum- an mati. Menurut Lemek (2003, p. 3), kejahatan yang keji, sangat bengis dan luar biasa yang merusak manusia lain baik dengan cara dibunuh atau diracuni seperti bandar narkoba, lebih baik dihukum mati, supaya tidak mengganggu ketenteraman dan merugikan orang lain serta dapat mengurangi angka keja- 
hatan. Salmi (1985, p. 93) mengungkapkan bahwa orang yang membunuh pantas dihukum mati. Seperti halnya dengan alasan yang dikemukakan oleh orangorang yang setuju dengan adanya hukuman mati, demikian juga mereka yang tidak setuju, memiliki alasan-alasan yang argumentatif. Pakar hukum, Todung Mulia Lubis, mengatakan bahwa hukuman mati, tidak pernah efektif, karena tidak melahirkan efek jera, terbukti perdagangan narkotika tetap saja tidak berkurang, meskipun sudah banyak yang telah dihukum mati (Lubis, 2005). Rachman (2018) mengungkapkan bahwa hukuman mati merupakan sebuah hukuman pokok yang diakui dalam sistem hukum positif Indonesia. Hal itu menunjukkan bahwa secara formal, hukuman mati telah diatur dalam sistem hukum yang berlaku di Indonesia.

Tjokro, mengatakan bahwa hidup bukan milik manusia, tetapi milik Tuhan, mengambil nyawa seseorang adalah hak Tuhan. Ketika manusia berbuat dosa, Tuhan memberi kesempatan kepada orang berdosa itu untuk menyesali perbuatannya atau bertobat. Oleh karena itu, manusia tidak berhak mengambil nyawa orang lain (Tjokro, 2003). Selain itu, Sahetapy juga menambahkan bahwa Indonesia mempunyai falsafah Pancasila. Pancasila itu tidak hanya menonjolkan atau mengutamakan sila ketuhanan yang maha Esa, tetapi harus secara eksplisit mengetengahkan ke empat sila lainnya, yakni kemanusiaan yang adil dan beradab, persatuan Indonesia, kerakyatan yang dipimpin oleh hikmat kebijaksanaan dalam permusyawaratan perwakilan dan keadilan sosial bagi seluruh rakyat Indonesia, supaya pemerintah dan hakim tidak sembarangan mengambil keputusan untuk menghukum mati orang yang melanggar undang-undang (Sahetapy, 1982).

Lembaga Bantuan Hukum mengatakan bahwa mati hidupnya seseorang hanya ditentukan oleh Tuhan, dan juga menurut filsafat hukum, hukuman itu bukan berarti pembalasan dendam, tetapi harus diartikan sebagai suatu cara untuk mendidik (Salmi, 1985, p. 99). Organisasi Kelompok Hapuskan Hukuman Mati (HATI) mengatakan bahwa merampas hak hidup seseorang, berarti meruntuhkan nilai-nilai kemanusiaan; Dari sudut Kriminologi, hukuman mati dirasakan kurang efektif dan dari tinjauan sosiologi, dipahami bahwa kejahatan tidak merupakan suatu tindak pidana mandiri dan perwujudan kehendak manusia semata-mata; kejahatan berkaitan erat dengan unsur sosial yang lain, sebab hukuman mati merupakan hukuman yang kurang adil (Salmi, 1985, p. 100).

Dalam tulisan Naiborhu (2016) diungkapkan bahwa dalam pandangan Kristen, hukuman mati bukan merupakan sebuah tindakan pembalasan, walau demikian menurut Naiborhu, hukuman mati diperlukan untuk menyeimbangkan keadaan yang terjadi akibat kejahatan. Sementara dalam kajian Sutoyo (2019) hukuman mati diperlukan terhadap pelaku korupsi karena dianggap sebagai sebuah kejahatan besar. Kemudian Zaluchu dan Gulo (2019) mengungkapkan bahwa hukuman mati selalu menjadi kontroversi walau demikian perlu sebuah kajian untuk meperkaya diskusi terkait hukuman mati. Umat Kristen atau Gereja, menurut Susanto (2019) memiliki tanggung jawab sebagai rekan negara untuk menghadirkan shalom di Indonesia. Jika demikian, dalam konteks kajian ini, penulis sebagai warga gereja perlu memberikan kontribusi kajian yang dapat bermanfaat bagi bangsa.

Berdasarkan argumentasi-argumentasi tersebut di atas, maka J.E. Sahetapy, Roeslam Saleh, Eka Darma Putra, meminta pemerintah Indonesia, untuk meninjau kembali tentang pelaksanaan hukuman mati di dalam KUHP, karena tidak sesuai lagi dengan Pancasila, khususnya sila kedua (Salmi, 1985). Orang-orang yang sama menuntut pemerintah dan Dewan Perwakilan Rakyat Republik Indonesia segera melakukan penghapusan pasal-pasal ancaman hukuman mati yang ada di dalam dan diluar KUHP (Tim penerjemah Badan Pembinaan Hukum nasional Departemen Kehakiman, 1983). Termasuk juga mendesak pemerintah untuk mengefektifkan grasi sebagai alat menolak penerapan atau eksekusi terhadap terpidana mati (Kitab Undang-undang Hukum Acara Pidana dan Penjelasannya, 1982). Dengan demikian, menjadi jelas bahwa ketentuan dan pelak- 
sanaan hukuman mati di Indonesia, masih menjadi kontroversi dan persoalan yang belum terselesaikan, serta diperdebatkan masyarakat dan para pakar hukum. Sementara itu, sampai hari ini Indonesia masih bertahan dengan ketentuan KUHP yang masih memberlakukan pelaksanaan hukuman mati. Oleh karena itu, perlu adanya suatu perspektif baru untuk memecahkan persoalan di atas yaitu solusi dan resolusi yang berdasarkan 'perspektif Alkitab'.

\section{METODE}

Metode yang digunakan dalam kajian ini adalah penelitian pustaka. Untuk membahas topik ini, penulis melakukan analisis terhadap beberapa literatur yang relevan. Topik ini dapat dikaji menggunakan pendekatan penelitian pustaka karena isu yang dibahas merupakan sebuah tatanan konsep teoritis. Dalam bidang teologi, penelitian ini menjadi sebuah tulisan yang meluaskan wawasan Kristen terkait dengan isu etika dan Teologi Praktika.

Hasil analisis terhadap beberapa literatur kemudian penulis sajikan secara deskriptif tematis. Sumber-sumber literatur yang digunakan merupakan sumber literatur yang berkaitan langsung dengan isu yang diteliti. Untuk menjalankan proses tersebut, mengacu pada Darmawan dan Asriningsari (2018) penulis terlebih dahulu harus memilih dan mencermati sumber pustaka yang relevan dengan topik ini.

\section{HASIL DAN PEMBAHASAN}

Pada bagian ini peneliti mendeskripsikan pengertian hukuman mati dan perspektif Alkitab tentang hukuman mati. Di kalangan praktisi dan pakar hukum, hal tentang ketentuan dan pelaksanaan hukuman mati bukanlah hal yang baru lagi. Tetapi di kalangan masyarakat umum, adalah sulit untuk memahaminya secara baik. Oleh karena itu, terlebih dahulu perlu dimengerti tentang istilah hukuman mati, baik umum maupun khusus. Menurut Kamus Istilah Hukum Indonesia, hukuman mati adalah hukuman yang dilaksanakan dengan membunuh, menembak atau menggantung orang yang bersalah (Surjountoro, 1974). Menurut Hamza dan Rahayu, hukuman mati adalah pidana yang terberat dari semua pidana, sehingga diancamkan kepada kejahatan yang amat berat saja (Hamzah \& Rahayu, 1983). Kriminolog, Lombroso dan Garofalo berpendapat bahwa hukuman mati berkaitan erat dengan istilah pidana mati yang berarti suatu kondisi kematian yang ditentukan oleh manusia, melalui badan yang berwewenang untuk menjatuhkan hukuman terhadap orang yang telah melakukan kejahatan yang amat berat. Hal itu dilakukan dengan tujuan yang sangat radikal yaitu untuk mempidanakan orang-orang yang tidak dapat diperbaiki lagi, dan dengan adanya pi-dana mati ini, maka hilanglah pula kewajiban untuk memelihara mereka dalam penjara-penjara yang demikian besar biayanya (Saleh, 1978). Zainal (1984) berpendapat bahwa pidana mati adalah suatu alat yang mutlak harus ada pada masyarakat untuk melenyapkan orangorang yang memang jahat dan sudah tidak dapat diperbaiki lagi.

Dengan demikian, maka definisi-definisi tersebut di atas dapat disimpulkan bahwa hukuman mati, harus ada dalam masyarakat sebagai alat negara atau alat hukum untuk mengatasi dan menghilangkan orang-orang dan perbuatan jahatnya yang dianggap tidak dapat diperbaiki lagi, walaupun tidak semua pakar dan masyarakat menyetujuinya.

\section{Perspektif Alkitab Tentang Hukuman Mati}

\section{Ketentuan Tentang Hukuman Mati}

Dalam Perjanjian Lama, kata atau istilah yang berkaitan dengan hukuman mati adalah ' $m a$ weth', artinya kematian, hukuman mati. Kata Ibrani ter-sebut digunakan 150 kali dalam Perjanjian Lama. Kata maweth berasal dari kata kerja 'Mut' yang diangkat dari bahasa Semit, artinya: die,kill, have one executed yang berarti mati, membunuh atau menghilangkan, seseorang yang dihukum mati (Unger \& White, 1980). Kata 'mut' dapat menunjuk kepada kematian dengan sebab-sebab natural atau kematian karena kekerasan. Hukuman mati merupakan akibat dari dosa atau pelanggaran manusia (Kej. 3:19). Kematian adalah indikasi penghakiman ilahi atas dosa 
(Kej. 2:17). Unger dan White menegaskan bahwa kematian Adam dan Hawa merupakan akibat dari pemberontakan melawan perintah Tuhan (Kej. 3). Tujuan Allah bagi Hawa dan Adam bukanlah kematian, tetapi hidup kekal. Kematian yang mulamula bukanlah keinginan Tuhan, melainkan merupakan hasil dari ketidaktaatan, kematian adalah konsekuensi dari dosa, semua itu bermula dari dosa (Unger \& White, 1980).

Jadi, berdasarkan penjelasan tersebut di atas, maka dapat ditegaskan bahwa hukuman mati ada karena adanya dosa. Tanpa adanya dosa, tidak pernah ada hukuman mati, contohnya disebutkan dalam Keluaran 21:12-17. Disana dijelaskan bahwa dosa atau pelanggaran, menyebabkan adanya hukuman mati, tetapi pada sisi lain juga dinyatakan bahwa ada keadilan Tuhan bagi orang yang membunuh sesama dengan tidak sengaja. Caranya adalah menyediakan daerah atau tempat perlindungan bagi mereka, sedangkan bagi mereka yang sengaja membunuh, dikenai hukuman yang setimpal yaitu hukuman mati (Bergant \& Karris, 2002).

Peraturan-peraturan yang diberikan Allah kepada bangsa Israel disebut 'hukum perjanjian' atau 'kitab perjanjian', yaitu perjanjian antara Allah dan bangsa Israel (Kel. 20:22 s.d.23:1). Setiap peraturan itu kemudian merupakan hukum dasar Israel yang menonjolkan penghargaan kepada pribadi manusia, sebagai nilai yang paling menonjol dibandingkan hukum yang lain di masyarakat timur tengah kuno (Bergant \& Karris, 2002). Penekanan pada keseluruhan peraturan ini, menunjuk kepada keistimewaan status bangsa Israel, sebagai umat pilihan Allah, sehingga mereka tetap terpelihara dalam nilainilai kebenaran ilahi dan tidak terpengaruh dengan kondisi dan niai-niai bangsa sekitarnya.

Di dalam Perjanjian Baru, istilah 'hukuman mati' (Mat. 15:4) berasal dari kata Yunani 'teteutao' dari kata dasar 'teleute' yang berarti: death, an end, accomplishment, to end, finish, complete (kematian, suatu akhir, penyelesaian menuju akhir, penghabisan, selesai). Secara intransitif, kata tersebut berasal dari kata Yunani 'bion' artinya kehidupan dunia, penuh, mengakhiri kehidupan seseorang, mati, tentang suatu kematian yang disebabkan oleh kekerasan (Mat. 15:4; Mrk. 7:10), dan must to be put to death, artinya harus mati (Zodhiates, 1996). Jadi hukuman mati berarti suatu tindakan untuk mematikan, mengakhiri hidup seseorang. Istilah ini mengandung pengertian yang sama dengan pengertian dalam Perjanjian Lama. Kematian yang dialami oleh manusia merupakan konsekuensi dari dosa atau ketidaktaatan manusia terhadap perintah Allah.

Berdasarkan Alkitab, kematian dibagi tiga kategori, yakni: kematian fisik, kematian spiritual dan kematian kekal. Dari ketiga kategori ini, yang berhubungan dengan hukuman mati, hanyalah kematian fisik. Kematian secara fisik merupakan akibat dari masuknya dosa melalui Adam dan Hawa kepada semua manusia, dan karena itu manusia diperbudak olehnya (Teney, 1980). Jadi, kematian yang dialami manusia adalah karena dosa keturunan dan dosa diri sendiri, maka dari situ manusia harus menerima hukuman dari Allah. Rasul Paulus, menghubungkan masalah 'kematian' dengan karya Kristus di kayu salib. Kemenangan atas kematian melalui karya Kristus (Salib dan Kebangkitan) serta konsekuensinya bagi pengharapan orang-orang percaya, merupakan tema utama yang mendominasi bagian besar dari seluruh Perjanjian Baru. Dari sana diperoleh pengertian, iman dan keyakinan bahwa di dalam Tuhan Yesus Kristus dan bersama dengan Dia saja, masalah kematian itu sendiri, baik kematian jasmani, kematian rohani dan kematian kekal, sudah selesai diatasi (Yoh.19:30) dan dimenangkan Kristus bagi manusia (I Kor. 15; Rm 6-8). Dengan demikian kematian (fisik, rohani dan kekal) bukan lagi persoalan yang tidak terselesaikan, tetapi persoalan yang benar-benar telah tuntas selesai dikerjakan oleh Kristus bagi manusia, masa kini didunia ini dan di dunia yang akan datang. Dengan bertolak dari perkataan Kristus dalam Yohanes 19:30,'sudah selesai' dan mengingat fakta kebangkitan Kristus dari antara orang-orang mati, serta berpegang pada keyakinan bahwa Kristus akan datang kembali menjemput orang percaya di awan-awan pada masa parousia, maka 
selesai sudah secara sempurna, persoalan kematian manusia. Yang paling penting untuk diingat dan dilakukan adalah bahwa siapapun manusia itu, semuanya pasti akan mati, baik karena dosa dan hukuman Allah maupun karena dihukum mati oleh sistem dan pelaksanaan hukum suatu negara yang ada di dalam dunia ini. Semua hukuman akibat dosa sudah selesai ditanggung oleh Yesus Kristus di atas kayu salib, asalkan manusia telah beriman kepada Kristus dan mentaati Dia selama di dunia ini, selama hayat di kandung badan. Inilah pengertian, keyakinan, iman, posisi dan status manusia berdosa yang sesungguhnya di hadapan Allah seperti ditegaskan dalam firman-Nya. Disini orang Kristen mempertahankan iman dan terus menjalankan pelayanan bagi Kristus dan sesama manusia.

Dengan demikian, ketentuan dan pelaksanaan hukuman mati di dalam konteks Perjanjian Baru, tidak perlu diberlakukan lagi, karena sudah diselesaikan dan ditanggung oleh Tuhan Yesus Kristus. Di dalam Perjanjian Baru, hal yang lebih diutamakan adalah kasih dari pada menghukum sesama manusia. Akibat dosa dan pelanggaran terhadap ketentuan-ketentuan Allah dan negara, harus tetap dijalankan secara fisik dan psikologis, tetapi tidak dengan 'hukuman mati', karena Kristus sudah menanggungnya bagi manusia secara sempurna. Lagi pula tidak ada manusia yang tidak berdosa di mata Tuhan, semuanya sudah berdosa dan karena itu membutuhkan Juruselamat dari dosa, yaitu Tuhan Yesus Kristus. Jadi tidak pantas dan sama sekali tidak benar menghukum mati orang yang bersalah, sejahat apapun (Rm 8:1-4; 2 Kor. 5:19-21).

\section{Pelaksanaan Hukuman Mati}

Geisler (2000), menjelaskan bahwa ada tiga pandangan dasar di kalangan Kristen tentang pelaksanaan hukuman mati, yakni (1) Rehabilitasionisme, suatu pandangan yang tidak mengizinkan hukuman mati untuk kejahatan apapun juga, (2) Rekonstruksionisme, suatu pandangan yang menuntut hukuman mati untuk semua jenis kejahatan yang serius dan (3) Retribusionisme, suatu pandangan yang menganjur- kan kematian untuk beberapa kejahatan besar. Verkuyl (2010) menjelaskan lebih lanjut bahwa Rehabilitasionisme tidak akan mengizinkan hukuman mati untuk kejahatan apapun juga, karena argumentasinya adalah bahwa 'tujuan dari keadilan untuk memperbaiki, bukan untuk menghukum seperti yang dinyatakan dalam Yehezkiel 18:23, 'Allah tidak senang dengan kematian orang fasik, tetapi berkenan kepada pertobatannya supaya ia hidup (2 Ptr 3:9).

Di dalam Perjanjian Lama, hukuman mati dinyatakan di dalam kitab Musa yang telah dibagi dalam dua bagian yaitu (1) Kejahatan yang dilakukan kepada Allah, seperti penyembahan berhala (Kel. 22:30); berpaling kepada Ilmu Sihir dan arwah (Kel. 22:18; Im. 20:6,27); menghujat nama Tuhan (Im. 24:14) dan tidak menguduskan hari sabat (Bil. 15:32) (Verkuyl, 1997). Dalam hubungan dengan sesama, hukuman mati ditetapkan khususnya untuk orang yang membunuh manusia, termasuk pembunuhan anak kecil (Kej. 9:6; Im. 20:1-5); orang yang mengutuk orang tua (Im. 20:9) dan untuk segala bentuk perzinahan (Im. 20:10-210). Hukuman mati dalam Perjanjian Lama, tidak lagi berlaku pada saat ini, karena Tuhan Yesus Kristus sudah menggenapi atau menganggungnya (Geisler, 2000).

Rekonstruksionisme, menganjurkan hukuman mati bagi kejahatan-kejahatan yang serius, artinya hukuman mati pantas diberikan kepada orang-orang yang telah melanggar kejahatan yang serius, seperti pembunuhan, alasannya karena hukum moral Allah yang dinyatakan kepada Musa tidak pernah dibatalkan; hukum moral bersifat tetap, sebab itu mencerminkan sifat Allah (Mat. 5:17). Tujuan keadilan adalah retribusi bukan rehabilitasi (Geisler, 2000, pp. 255-256). Jadi, menurut pandangan ini, hukuman mati dapat diterapkan, karena sesuai dengan hukum moral Allah.

Retribusionisme, mengajarkan tentang hukuman mati, untuk beberapa kejahatan. Alasannya, hukuman mati sudah diberlakukan sejak manusia pertama, Adam dan Hawa (Kej. 4), kemudian berlaku pada zaman Nuh, Musa dan bahkan Allah telah 
memberi kuasa kepada pemerintah (Rm. 13:1,4) untuk melaksanakannya sampai saat ini. Pedang yang diberikan Allah kepada pemerintah, tujuannya adalah untuk pelaksanaan hukuman mati bagi orangorang yang melanggar perintah Tuhan. Jadi jelas bahwa, ketiga pandangan ini, dianut oleh orangorang Kristen dan umum, karena masing-masing pandangan didasarkan pada Alkitab.

Pandangan Rehabilitasionisme berpendapat orang jahat jangan dihukum tetapi diampuni dan diperbaiki, sedangkan dua pandangan lainnya berpendapat bahwa orang-orang jahat, harus dihukum atau harus menerima balasan yang sesuai dengan perbuatannya. Timbul pertanyaan yang sangat penting untuk dijawab secara tuntas yaitu, apa dan bagaimana sebenarnya, pandangan Alkitab yang komprehensif dan integratif tentang ketentuan dan pelaksanaan hukuman mati itu? Dalam penelitian ini jawabannya adalah: (1) Kembali kepada Allah dan Alkitab, firman-Nya, (2) Pandangan Alkitab yang satu, tidak boleh dipertentangkan dengan pendapat Alkitab lainnya; masing-masing pandangan harusnya ditempatkan pada konteks dan posisinya masing-masing secara proporsional, karena semuanya itu berasal dari Allah yang satu dan sama, itulah Allah Alkitab, walaupun mungkin nampak adanya 'paradoks'. Oleh karena itu, dalam implementasinya, perlu: (1) Menggabungkan pandangan-pandangan tersebut tadi, (2) menempatkan pada posisi dan kondisinya masing-masing, supaya saling melengkapi dan saling menunjang dan (3) Puncaknya adalah menempatkan semua pandangan-pandangan Alkitabiah tersebut di dalam penggenapannya yang sempurna, di dalam Tuhan Yesus Kristus, karena hanya Dialah Penggenap dan Penyempurna serta Pelaksana semua hukum dan hukuman Allah yang seharusnya ditanggung oleh semua manusia berdosa. Di dalam Tuhan Yesus Kristus dan karya-Nya yang sempurna bagi manusia, semua hukum dan hukuman Allah sudah dijalankan dan diselesaikan-Nya. Hukuman untuk tubuh manusia (kematian fisik) sudah ditanggung Kristus di dalam tubuhnya sendiri, hukuman rohani sudah dipikulnya, dan ditanggung-Nya, hukuman kekal juga sudah ditanggung-Nya bagi manusia dengan karya penebusan-Nya yang sempurna tersebut. Karena itu, yang paling penting dari semuanya adalah bahwa orang Kristen memiliki iman, pengertian dan pengetahuan akan karya Kristus seperti tersebut di atas dan menghidupinya dengan pertolongan Roh Kudus di dalam seluruh aspek hidup orang Kristen, demi kemuliaan Tuhan dan keselamatan sesama manusia.

Kristus telah mengampuni segala dosa manusia, dosa kepada Tuhan Allah, dosa kepada orang lain dan kepada diri sendiri. Oleh karena itu wajib bagi orang Kristen untuk saling mengampuni di dunia ini dan sampai di akhirat. Inilah moralitas Kristiani. Persoalannya belum selesai. Bagaimana dengan negara-negara, termasuk Indonesia, yang masih memberlakukan hukuman mati bagi kejahatan yang luar biasa? Jawabannya adalah, orang Kristen mesti berjuang lewat jalur hukum dan jalur politik, serta jalur yang lain yang legal, agar hukuman mati diganti dengan hukuman seumur hidup untuk kejahatan yang luar biasa itu. Dengan demikian orang yang bersalah masih mendapatkan kesempatan untuk bertobat dan diampuni oleh Tuhan dan berdamai dengan sesama. Akibat dosa tetap harus ditanggung, tetapi dosanya telah diampuni oleh Tuhan, negara dan sesama. Alkitab menegaskan bahwa Allah tidak berkenan kepada kematian orang fasik, tetapi kepada pertobatannya. Inilah pandangan Kristen yang alkitabiah, yaitu pandangan yang didasarkan kepada 'hukum moral Allah' dan 'hukum kasih karunia Allah' yang sempurna di dalam Kristus.

Jadi, hukum manusia dan hukum negara, belum cukup dalam mengatasi persoalan hukuman mati. Manusia masih memerlukan 'hukum kasih karunia Allah' yang mengatasi dan menyempurnakan hukum negara dan hukum moral universal. Hukum moral didasarkan pada sifat-sifat Allah yang 'Suci dan Adil', dan karena itu mengharuskan adanya disiplin, hukuman dan keadilan bagi orang berdosa serta 'hukum kasih karunia' Allah yang ada di dalam Kristus, mengharuskan manusia yang berdosa, sejahat apapun untuk diberi kesempatan menerima 
dan mengalami pengampunan Allah melalui pertobatan, sekalipun harus memikul dan menanggung semua konsekuensi dari perbuatan dosanya. Ini baru namanya keadilan bagi yang bersalah dan berdosa, bukan hanya keadilan bagi sang korban dan bagi penegakkan hukum. Nampak disini bahwa hukum negara dan hukum moral universal serta jenis hukum yang lain yang ada di dunia ini, masih perlu diberi nilai dan muatan theologis (hukum moral dan hukum kasih karunia Allah yang bersifat komprehensif dan integratif) demi penyempurnaannya. Oleh sebab itu hukum yang diberlakukan di dalam suatu negara dan bangsa benar-benar merefleksikan dan mewujudkan hukum-hukum Allah yang sempurna. Dalam konteks dan pengertian seperti ini, negara benar-benar berfungsi dan bertugas menjalankan 'kehendak Allah' bagi ketertiban, kebaikan dan kesejahteraan manusia.

\section{Dampak Hukuman Mati}

Keadilan dan kasih Allah yang seimbang dan integratif, harus menjadi standar dan patokan, baik untuk penegakkan ketentuan Allah untuk hukuman mati dan pelaksanaannya, maupun dalam mengukur dampak yang ditimbulkannya. Pemahaman dan pengertian yang benar-benar komprehensif Alkitabiah tentang keadilan dan kasih karunia Allah, pasti memberi dampak yang adil dan proporsional bagi Allah, bagi pelaku kejahatan dan bagi si korban. Dampaknya bagi Allah adalah: (1) Allah sendiri diperlakukan sebagai Allah yang adil dan kasih adanya yang ujung-ujungnya Allah disenangkan, ditaati, dihormati dan dipuji selamanya; (2) dampaknya bagi pelaku kejahatan (dari kejahatan yang kecil sampai kejahatan yang paling keji di mata Allah dan hukum) adalah bahwa yang bersangkutan diberikan 'anugerah khusus' untuk bertobat dan beroleh pengampunan Allah, sesama dan negara (hak hidupnya diberikan kembali). Ini adalah wujud dari hukum Allah yang kedua yakni 'kasihilah sesamamu manusia seperti dirimu sendiri' dan (3) dampaknya bagi korban kejahatan adalah bahwa ia beroleh kesempatan untuk menerima 'anugerah Allah' untuk meng- ampuni orang yang bersalah kepadanya. Ini adalah wujud atau penggenapan firman Allah dalam Matius 6:12 yang berkata, 'Ampunilah kami akan kesalahan kami, seperti kami juga mengampuni orang yang bersalah kepada kami'. Tantangannya bagi orangorang Indonesia adalah, apakah sistem hukum dan peradilan di Indonesia sudah mengakomodasi hukum kasih karunia Allah ini baik dalam KUHP maupun dalam pelaksanaannya?

Pengampunan dari Allah terhadap sesama dan diri sendiri, dan pelaksanaannya dalam praktek hidup, adalah solusi dan resolusi terbaik bagi penyelesaian masalah ketentuan dan pelaksanaan hukuman mati. Karena Tuhan Yesus sendiri telah mati dan membayar semua dosa-dosa dan kesalahan secara sempurna sekali untuk selamanya. Kebenaran ini nyata dalam perkataan Kristus di atas kayu salib: 'Ampunilah mereka, sebab mereka tidak tahu apa yang mereka perbuat' (Luk. 23:34). Kejahatan yang diperbuat oleh pemerintahan Romawi untuk Kristus, dengan menyalibkan-Nya adalah jenis kejahatan yang sangat luar biasa (Extra Ordinary crime). Tetapi Kristus sudah mengampuni mereka. Seharusnya, baik penguasa Romawi maupun para eksekutor hukuman mati terhadap Kristus, merekalah yang pantas dan layak dihukum mati, karena telah melakukan kejahatan yang paling keji terhadap kemanusiaan Kristus, apalagi Kristus tidak bersalah sama sekali. Inilah paradoks ilahi/theologis yang perlu dipikirkan sedalam-dalamnya, sebagai bagian untuk membangun sistem hukum yang berkeadilan dan berkasih karunia. Alkitab menegaskan, semua hukuman Allah bagi manusia, baik hukuman fisik yang ujungnya adalah kematian jasmani, hukuman rohani (tidak ada hubungan dengan Allah) dan hukuman kekal di Neraka (terpisah dari Allah selamanya) sudah selesai sempurna ditanggung Kristus lewat pengorbanan-Nya di kayu salib. Dari karya pengorbanan Kristus yang sama manusia semua berhak mendapatkan 'kasih karunia Allah' yang sempurna dan abadi bagi penyelamatan hidup di dunia ini sampai seterusnya di akhirat nanti. 


\section{Relevansinya Bagi Para Penegak Hukum Kristen Di Indonesia}

Relevansi tentang ketentuan, pelaksanaan dan dampak hukuman mati di Indonesia berdasarkan Alkitab ditinjau dari empat aspek yakni : (1) Situasi dan kondisi penegakkan hukum di Indonesia,(2) Tugas-tugas Penegak hukum Kristen (3) Tanggung jawab penegak hukum Kristen dan (4) Pengambilan keputusan penegak hukum Kristen.

\section{Situasi dan Kondisi Penegakan Hukum di Indonesia}

Negara Indonesia mempunyai jumlah penduduk terbesar ke empat di dunia. Jumlah penduduknya 265 juta jiwa. Wilayah Indonesia terdiri dari 18.160 pulau, didiami oleh beragam suku bangsa, bahasa dan kebudayaan serta adat-istiadat yang berbeda-beda (Octavianus, 2015). Negara Indonesia juga adalah negara hukum yang berdasarkan 'Pancasila' dan Undang-Undang Dasar 1945 (UUD 1945), yang menjunjung tinggi hak asasi hukum dan hak asasi manusia, baik di tingkat pemerintahan maupun di masyarakat serta memprioritaskan penegakkan ketertiban dan keamanan bangsa. Dengan adanya hukum dan peraturan perundang-undangan yang telah berlaku, diusahkan supaya ketertiban dan keamanan masyarakat terpelihara secara berkesinambungan. Tetapi dalam kenyataannya, masih ada orang-orang, kelompok-kelompok masyarakat yang melanggar Undang-Undang dan peraturan-peraturan hukum yang berlaku, sehingga belum tercipta suatu negara yang 'aman, damai dan tertib' di dalam banyak bidang kehidupan. Penegakkan hukum masih dianggap lemah oleh banyak pakar hukum; praktek penegakkan hukum dinilai masih tumpul ke atas (kepada orang-orang yang berkuasa dan kaya) tetapi tajam ke bawah (kepada orang-orang biasa). Pelanggaran terhadap hak-hak asasi manusia, masih marak terjadi di mana-mana di Indonesia.Moralitas bangsa ini masih rapuh, jika berhadapan dengan pengaruh globalisasi yang sangat liberal dan sekularistik. Penyalahgunaan agama dan ayat-ayat kitab suci, masih terjadi atas nama perebutan pengaruh dan ke- kuasaan. Penyalahgunaan obat-obat terlarang (Narkotika) masih marak terjadi di banyak tempat di negeri ini. Usaha dan perjuangan mendirikan negara khilafah, masih terus bergulir di negeri ini. Diskriminasi atas dasar agama, suku dan antar golongan (SARA) belum selesai di negeri ini. Keadilan sosial masih jauh dari harapan akibat penegakan hukum yang lemah. Hal-hal ini, jelas-jelas bertentangan dengan Kitab Undang-Undang Hukum Pidana (KUHP) yang berlaku di Indonesia (Tim Penterjemah Badan Pembinaan Hukum Nasional Departemen Kehakiman, 1983). KUHP ini sudah mengatur tentang sanksi hukum bagi pelanggaran dan kejahatan yang dilakukan oleh setiap warga negara. C.S.T. Kansil menjelaskan bahwa dalam ilmu hukum istilah pelanggaran dan kejahatan memiliki perbedaan: Pelanggaran ialah mengenai hal-hal kecil atau ringan, yang diancam dengan hukuman denda, misalnya sopir mobil yang tidak memiliki surat izin mengemudi (SIM), bersepeda tanpa lampu merah pada malam hari dan lain-lain. Sedangkan kejahatan adalah mengenai soal-soal yang besar, seperti pembunuhan, penganiayaan, pencurian dan sebagainya. Contoh pelanggaran dan kejahatan terhadap kepentingan umum yang berkenaan dengan Badan/Peraturan Perundangan negara, misalnya pemberontakan, penghinaan, tidak membayar pajak, melawan pegawai negeri yang sedang menjalankan tugas; dan kepentingan tiap-tiap manusia, misalnya terhadap jiwa ialah pembunuhan, terhadap tubuh yakni penganiayaan, terhadap kemerdekaan adalah penculikan, terhadap kehormatan yaitu penghinaan dan terhadap milik adalah pencurian (Kansil, 1989).

Peraturan-peraturan tentang jiwa, raga, milik dan sebagainya dari tiap-tiap orang, telah temasuk dalam hukum perdata, sedangkan masalah pembunuhan, pencurian dan sebagainya diatur dan diurus oleh pengadilan pidana. Tugas untuk menegakkan hukum dan keadilan seperti mengatasi pelanggaran dan menghukum kejahatan adalah tugas pemerintah yang telah dipilih dan ditetapkan oleh Allah (End, 2015). Hal ini menunjukkan bahwa semua pemerintah adalah utusan Tuhan untuk mengatur mas- 
yarkat. Tujuan Tuhan menetapkan pemerintah adalah untuk melindungi dan mengatur tata kehidupan manusia yang ada di bumi ini; dan menghukum orang-orang yang melanggar ketentuan-ketentuan yang telah ditetapkan. Tetapi di dalam menghukum seseorang, atau sekelompok orang, pemerintah tidak memiliki hak untuk menghukum mati para penjahat, karena dalam pengertian Alkitab yang komprehensif, jelas dikatakan bahwa 'hak' hidup manusia harus dihargai dan tidak diperkenankan menghilangkan nyawa sendiri atau nyawa orang lain (Ayub 1:12a; 2:6). Ayat ayat ini menegaskan bahwa nyawa manusia adalah berasal dari Tuhan dan milik Tuhan, bukan milik iblis, bukan milik pemerintah, bukan milik sesama manusia (Baruch, 2010). Nilai, harga dan martabat manusia serta seluruh keberadaannya, adalah milik Tuhan dan sudah lunas dibayar oleh 'darah' Kristus Yesus (1Korintus 6:1920). Tuhan melarang siapapun, supaya tidak boleh merusak atau merombak tubuh manusia sebagai 'bait Allah' (1 Kor. 3:16-17). Eksistensi dan esensi satu nyawa manusia sepenuhnya adalah milik Allah, karena itu tidak boleh ada satu manusia pun yang boleh membunuhnya. Dalam hal ini, negara tidak boleh mengambil posisi Allah dalan hal memvonis mati seseorang. Jangan sampai pemerintah mengambil hak dan posisi Allah, pemerintah jangan melawan kehendak Allah. Pemerintah dan seluruh perangkatnya, wajib menjalankan seluruh ketentuan Allah untuk hidup manusia. Jangan sampai negara /pemerintah melawan kehendak Allah dan karenanya menerima kutuk dan penghukuman Allah karena bertindak sewenang-wenang tanpa keadilan dan kebenaran.

\section{Tugas Penegak Hukum Kristen}

Ketika Allah selesai menciptakan manusia,maka Ia menempatkan manusia di taman Eden dan Allah memberi mereka kuasa untuk memelihara binatang, tumbuh-tumbuhan, tanah dan yang lain. Disinilah sumber kerja manusia pertama. Kerja adalah hal positif yang diberikan Allah sebagai berkat dan bukan sebagai akibat dosa (Sitompul, 2015, p. 4). Didalam penciptaan manusia, Tuhan sekaligus memberikan amanat kepada manusia untuk menaklukan bumi dengan segala isinya, supaya manusia mendapat makanan dari dalamnya. Dengan perkataan lain, amanat kebudayaan dinyatakan dan diberikan kepada manusia, setelah manusia diciptakan dan sebelum manusia jatuh ke dalam dosa. Manusia mempunyai tanggung jawab untuk mengelolah bumi ini. Segala kemungkinan yang ada harus diusahakan, harus dikelola sehingga terwujudlah ungkapan, manusia sebagai manusia yang berbeda dengan mahluk yang lain (Sihombing, 2014). Manusia dipercayakan untuk mengatur, memelihara dan melestarikan semua yang ada di bumi ini. Segala kemampuan dan kebebasan yang diberikan Allah kepada manusia, dimaksudkan supaya, digunakan semaksimal mungkin untuk mengemban amanat Tuhan ini (Amanat Kebudayaan). Sedangkan perintah dan tugas kepada pemerintah, dinyatakan dalam Mazmur 72 dan Roma 13. Mazmur 72:2 menyatakan: 'Kiranya Ia mengadili umat-Nya dalam kebenaran dan orangorang-Mu yang tertindas dalam hukum'. Hal yang sama ditegaskan lagi dalam pasal yang sama ayat 4,5,12-14. Disitu ditunjukkan bahwa kekuasaan dan kewibawaan dari seorang pemimpin atau raja, tidak didapat dari diri dan usaha sendiri, tetapi dari Allah dan dari umat Allah. Dalam Roma 13:1 dan 4 dikatakan:

'Tiap-tiap orang harus takluk kepada pemerintah yang di atasnya, sebab tidak ada pemerintah, yang tidak berasal dari Allah; dan pemerintahpemerintah yang ada, ditetapkan oleh Allah; Karena pemerintah adalah hamba Allah untuk kebaikanmu, tetapi jika engkau berbuat jahat, takutlah akan dia, karena tidak percuma pemerintah menyandang pedang; pemerintah adalah hamba Allah untuk membalaskan murka Allah atas mereka yang berbuat jahat. Tugas dan panggilan Allah ini, berlaku untuk pemerintahan manapun di dunia ini, dari dahulu sampai sekarang. Ada tiga tugas pemerintah sebagai pelayan bagi masyarakat, bangsa dan negara yakni:

(1) Mendapatkan dan menjalankan kekuasaan Allah,

(2) Membangun dan menegakkan keadilan/kesucian 
Allah dan (3) Menerapkan Cinta kasih Allah, dalam tugas dan penugasan melayani masyarakat, dan akhirnya wajib mempertanggungjawabkan semuanya itu kepada Pemberi tugas itu sendiri, Yakni Tuhan Allah.

Setiap pemerintahan memerlukan kekuasaan untuk dapat berfungsi sebagai pelayan dan pelindung masyarakat. Ada dua kuasa umum yang diberikan Allah kepada pemerintah, yakni: (1) Pemerintah berhak menarik pajak dari rakyat dan (2) Pemerintah mempunyai kuasa untuk memegang dan menggunakan pedang. Artinya pemerintah harus mempunyai sistem pertahanan dan militer (Rm. 12:4-7) serta pemerintah wajib memiliki sistem dan kekuatan ekonomi supaya dapat menjalankan fungsi, tugas dan tanggung jawab dengan baik dan lancar dan juga supaya pemerintah mampu membela diri, melawan musuh-musuh dan mensejahterahkan masyarakat. Dengan cara demikian, dapat tercipta kehidupan masyarakat yang tertib, damai, tenteram dan harmonis, dan semuanya itu berasal dari Allah (Rm. 12:10,18) (Geisler, 2000, p. 227).

Sebaliknya, jika pemerintah menganiaya orangorang Kristen (Gereja Yesus Kristus), melakukan ketidakadilan, mendukung kejahatan moral, menginjak-injak hak orang-orang lemah dan tidak berdaya, dan jenis kejahatan lainnya, maka pemerintahan seperti itu, tidak dapat dipandang sebagai 'pemerintah yang ditetapkan Allah'. Karena kejahatan-kejahatan seperti itu, bertentangan dengan kehendak dan tujuan Allah melalui praktek pemerintahan. Tujuan Allah adalah supaya melalui hamba-hambaNya, para pejabat pemerintahan yang melakukan tindakan-tindakan jahat dihukum secara benar, adil dan kasih bagi semua pihak (Baruch, 1996, p. 68). Implementasi kekuasaan negara adalah demi kepentingan keadilan, kebenaran dan kasih karunia Allah bagi semua. Tuhan adalah adil dan karena itu tugas pemerintah adalah berlaku dan bertindak seadil-adilnya dalam kasih dan kebenaran Allah. Pemerintah dipanggil dan ditetapkan untuk menghormati dan menjamin hak-hak seseorang serta mengutamakan kepentingan umum daripada kepen- tingan pribadi. Sebab di mana ada keadilan, disitu akan terdapat ketenteraman dan damai sejahtera (Yes. 32:17). Tugas dan tanggung jawab pemerintah disamping menjalankan keadilan, juga adalah mengusahakan cinta kasih kepada semua anak bangsa. Alasannya adalah karena Tuhan Allah sendiri adalah kasih adanya dan bahkan penuh kasih karunia (Yoh. 1:16). Pemerintah wajib bertindak berdasarkan kasih dan keadilan Allah yang proporsional dan integratif kepada semua anak bangsa, terutama bagi mereka yang tertindas, terbelakang, kurang beruntung dan terpinggirkan karena ketidakadilan, termasuk kepada mereka yang berbuat kejahatan yang luar biasa.

Di dalam Lembaga hukum di Indonesia, Tuhan menempatkan banyak penegak hukum beragama dan berkeyakinan Kristen. Hal itu, bukanlah suatu kebetulan, tetapi sudah diatur oleh Tuhan sendiri. Oleh sebab mereka mempunyai tugas khusus dari Tuhan untuk dunia hukum dan peradilan, yakni tugas memperjuangkan tegaknya keadilan dan kasih karunia Allah bagi masyarakat, seperti yang Tuhan kehendaki. Badan penegak hukum di Indonesia memiliki tugasnya masing-masing, selain tugas-tugas tersebut di atas. Tugas Polisi adalah memelihara ketertiban dan menjamin keamanan umum; mencegah dan memberantas kejahatan; memelihara keselamatan masyarakat, benda dan orang; menyelidiki kasus; memberi pertolongan, mengusahkan ketaatan warga negara terhadap peraturan-peraturan negara serta menjaga dan mengatur lalu lintas (Arief, 2001, p. 2). Tugas jaksa adalah menerima dan memeriksa berkas perkara penyelidik dari penyidik atau penyidik pembantu, memberikan perpanjangan penahanan, membuat surat dakwaan, melimpahkan perkara ke pengadilan, melakukan penuntutan, menutup perkara demi kepentingan umum, melaksanakan penetapan hakim dan sebagainya (Kansil, 1989). Tugas hakim yang lain adalah memberi kesempatan kepada si terhukum untuk membela diri terhadap tuduhan-tuduhan jaksa dan para saksi. Tugas dari Mahkamah Agung adalah memeriksa dan memutuskan permohonan kasus sengketa tentang 
kewenangan mengadili dan permohonan peninjauan kembali putusan pengadilan yang telah memperoleh kekuatan hukum tetap (Kansil, 1989).

Dalam menjalankan tugas, sebagai penegak hukum Kristen yang berwawasan Aklitab, wajib memiliki visi kristiani yang jelas tentang kasih dan keadilan Allah, mempunyai motivasi yang murni dari Allah, memiliki kesungguhan bekerja, dan menjaga persahabatan yang baik dengan rekan sekerja dan masyarakat. Sebelum menjalankan tugas dan pekerjaan, selalu memprioritaskan Tuhan dalam hidup pribadinya, supaya selalu mengalami bantuan Tuhan dan hikmat dari Tuhan. Penegak hukum Kristen harus selalu menggunakan kekuasaan, keadilan dan cinta kasih Allah kepada sesama secara proporsional dan bertanggungjawab. Sebagai warga negara yang baik, orang-orang Kristen wajib bekerja sama dengan pemerintah dalam menjalankan dan memperlancar roda pemerintahan supaya tercapai apa yang diharapkan masyarakat dan bangsa, yakni hidup yang aman, damai dan sejahtera dengan sesama, diri sendiri dan Tuhan.

\section{Tanggung Jawab Penegak Hukum Kristen}

Istilah 'tanggung jawab' berkaitan dengan kata 'jawab'. Bertanggung jawab berarti dapat menjawab, jika ditanya tentang perbuatan-perbuatan yang dilakukan. Tanggung jawab berarti orang tidak boleh mengelak, apabila diminta penjelasan tentang perkataan dan perbuatannya. Jawaban itu harus diberikan kepada Tuhan, masyarakat dan diri sendiri (Berten, 1993, p. 125). Penegak hukum Kristen dalam menjalankan profesinya, bertanggung jawab kepada Tuhan Allah, pemerintah dan masyarakat. Tanggung jawab tersebut dapat diwujudkan dengan: (1) Terus mendoakan negara dan pemerintah supaya disana ada rasa dan kesadaran takut akan Tuhan, dalam pelaksanaan tugas-tugas hukum dan peradilan, (2) Bertanggung jawab menasehati para penegak hukum lainnya supaya berlaku jujur dalam menegakkan keadilan dan kebenaran dan (3) Bertanggung jawab kepada masyarakat, dengan cara, mengusahakan, memelihara dan memberi kesejah- teraan, rasa aman dan tenteram kepada mereka, sehingga ia dapat dipercaya; caranya adalah membela orang benar dan mengadili orang yang salah tanpa pandang muka, kedudukan, kekayaan dan jabatan seseorang (J. Verkuyl, 2010, p. 101), (4) Bertanggung jawab kepada diri sendiri, hal tersebut dapat diwujudkan dengan berlaku jujur terhadap diri sendiri, dapat menerima diri sendiri apa adanya dan tidak boleh merasa diri bersalah, sehingga dapat menjalankan tanggung jawab dengan baik dan rasa aman dan (5) Bertanggung jawab untuk selalu menjadi garam dan terang Kristus di tengah-tengah dunia peradilan dan hukum. Dengan demikian dapat mencegah pelanggaran, kebusukan dan kerusakan praktik-praktik hukum di Indonesia (Mat. 5:13-16).

\section{Pengambilan Keputusan Penegak Hukum Kristen}

Indonesia adalah negara yang agamis dan berpancasila, dengan keyakinan bahwa Tuhanlah yang berhak memberi hak hidup dan Tuhan jugalah yang berhak mencabut hidup atau nyawa manusia. Hak Tuhan ini, wajib dikembalikan kepada-Nya dan tidak boleh diambil alih siapa pun juga. Ini adalah hak asasi Tuhan yang tidak boleh dilanggar oleh hukum, peraturan dan ketentuan-ketetuan yang dibuat oleh manusia. Biarkan Tuhan berdaulat atas hak-Nya sebagai Pemberi dan pencabut Nyawa seseorang. Jangan dilanggar oleh manusia, nantinya akan mendapat penghukuman Allah di dunia dan akhirat. Kenyataannya, Lembaga pengadilan dan para hakim serta penegak hukum lainnya, berhak mencabut hidup dan nyawa seseorang di negeri ini, melalui vonis mati. Pertanyaannya adalah apakah kedudukan, wewenang para penegak hukum itu sama persis semuanya dengan hak, wewenang dan kuasa sang Pencipta, Hakim Maha Agung itu? Di sisi lain, para polisi, jaksa, hakim adalah manusia biasa yang juga turut bertanggung jawab memberi vonis mati kepada seorang atau beberapa orang penjahat. Bukankah mereka hanya manusia biasa yang menjalankan tugasnya berdasarkan ketentuan Undang-Undang negara? Bukankah mereka juga bertindak untuk suatu kepentingan yang lebih besar yakni kepenting- 
an masarakat luas dan negara ini? Lalu bagaimana dengan kepentingan Tuhan di dalam konteks seperti ini? Pertanyaan seperti ini dan pertanyaan lainnya yang searah dengan itu, patut untuk direnungkan oleh seluruh elemen masyarakat, utamanya mereka yang bertugas dan bertanggung jawab dalam penegakkan hukum dan keadilan. Dan lebih khusus lagi bagi para penegak hukum Kristen yang tidak lain adalah 'hamba-hamba Allah' di dunia hukum dan peradilan?

Hukuman mati, bukan harga mati untuk memenuhi prinsip penegakan hukum. Hukuman mati wajib dilihat dari aspek rasa kemanusiaan dan rasa keadilan serta dari aspek hati nurani manusia itu sendiri. Bukan saja dari sudut si Pelaku tetapi juga dari sudut pandang si korban. Sejatinya pemerintah, masyarakat maupun penegak hukum saat ini, hanya melihat dari kacamata formalitas saja, ketika hakim memponis mati seseorang. Tetapi jangan lupa bahwa polisi, jaksa dan hakim hanya bisa berpijak dan mengetok palu keadilan menurut kitab undang-undang negara yang dibuat oleh manusia, dalam hal ini oleh pemerintah, tetapi belum tentu menurut suara hati manusia yang murni. Suara hati manusia yang murni adalah hukum Allah yang tertanam di dalam diri manusia, yang mengingatkan manusia siapa sebenarnya dirinya ini (Rm. 2:14-16). Ayub 44:22b menegaskan: 'Karena Ia (Allah) mengetahui rahasia hati.' Melalui keberadaan hati nurani ini, manusia tidak dapat menipu dirinya sendiri (White, 2015). Oleh karena itu, penegak hukum Kristen, harus mengetahui bagaimana mengambil keputusan yang benar sesuai dengan 'kehendak Tuhan' dan bagaimana mengatasi kejahatan sehingga tidak merugikan diri sendiri, orang lain, si korban dan kebenaran itu sendiri.

Pada umumnya, orang-orang Kristen berpendapat bahwa Allah adalah pusat dan sumber dari semua yang baik dan benar. Allah adalah Hakim yang terakhir yang memutuskan apa dan siapa yang benar serta apa dan siapa yang salah. Semua moralitas tunduk kepada ketentuan-Nya. Oleh sebab itu, di dalam pengambilan keputusan, para penegak hukum
Kristen, harus mencari kehendak Tuhan,walaupun mungkin tidak sesuai dengan kehendak manusia (Brownlee, 2015, p. 29). Selain itu sebagai orang Kristen, dalam pengambilan keputusan, haruslah didasarkan pada doa yang benar dan sunguh-sungguh. Doa perlu dipandang bukan hanya sebagai jalan untuk memohon bimbingan Tuhan untuk suatu keputusan yang sulit, tatapi juga sebagai cara mengakrabkan orang percaya dengan Tuhan (Brownlee, 2015, p. 241). Sebagai penegak hukum Kristen, para penegak hukum perlu selalu hidup di dalam hikmat Roh Kudus dan Alkitab, yang memampukannya mengenal kehendak Allah dalam mempertimbangkan, menganalisis dan mengambil keputusan-keputusan hukum. Para penegak hukum Kristen, dalam mengambil keputusan, tidak hanya bertolak dari peraturan perundangan saja (karena peraturan manapun selalu ada titik lemahnya), tetapi juga harus berdasar pada sumber kebenaran Kristen yakni, Allah Tritunggal dan hikmat Alkitab di dalam inspirasi dan iluminasi Roh Kudus. Karena setiap orag Kristen sudah mengetahui kebenaran Allah ini, bahwa manusia telah diciptakan serupa dan segambar dengan diri-Nya (Kej. 1:26-28), dan berharga di mata Tuhan (Yes. 43:4). Allah saja sebagai Pencipta manusia, sangat mengasihi orang-orang berdosa (Yes. 1:18), termasuk mereka yang dihukum mati menurut undang-undang buatan manusia yang banyak kelemahannya, apalagi para penegak hukum Kristen yang diciptakan menurut rupa Allah, seharusnya, wajib mengasihi para penjahat yang didakwa hukuman mati itu. Firman Allah berkata, dalam situasi seperti ini, orang Kristen harus lebih taat kepada Allah dari pada kepada manusia (Kis. $4: 19)$.

\section{KESIMPULAN}

Di kalangan orang-orang Kristen sendiri, terdapat tiga pandangan tentang ketentuan dan pelaksanaan hukuman mati. Kelompok Rehabilitasionisme, menolak ketentuan dan pelaksanakan hukuman mati untuk jenis kejahatan apapun juga. Alasannya adalah bahwa tujuan dari keadilan untuk 
memperbaiki bukan untuk menghukum. Yehezkiel 18:23 menegaskan Allah tidak senang dengan kematian orang fasik, tetapi berkenan kepada pertobatannya, supaya ia hidup' (2 Ptr. 3:9)'. Kelompok Retribusionisme menganjurkan hukuman mati bagi beberapa kejahatan besar dan serius. Alasannya karena hukuman mati sudah diberlakukan sejak manusia pertama, Adam dan Hawa (Kej. 4), kemudian berlaku pada zaman Nuh, Musa dan Allah telah memberi kuasa kepada pemerintah-pemerintah untuk melaksanakannya sampai hari ini ( $\mathrm{Rm}$. 13:1,4). Kelompok Rekonstruksionisme mendukung ketentuan dan pelaksanaan hukuman mati untuk kejahatan-kejahatan yang serius. Alasannya karena hukum moral Allah yang diberikan kepada Musa, tidak pernah dibatalkan. Hukum moral ini adalah cerminan sifat Allah (Mat. 5:17). Jadi hukuman mati dapat diterapkan karena sesuai dengan Alkitab

Dalam Alkitab ketentuan dan pelaksanaan hukuman mati dapat dikategorikan dalam tiga fase: (1) Dalam zaman Musa, hukuman mati diberlakukan untuk pelanggaran dan dosa terhadap Allah, seperti penyembahan berhala (Kel. 22:30), berpaling kepada ilmu sihir dan arwa orang mati (Kel. 22:8; Im. 20:67), menghujat nama Tuhan (Im. 24:14) dan tidak menguduskan hari Sabat (Bil. 15:32); (2) Pelanggaran dan dosa terhadap sesama manusia seperti membunuh manusia termasuk anak kecil (Kej. 9:6; Im. 20:1-5), mengutuk orang tua (Im. 20:9), dan segala bentuk perzinahan (Im. 20:10-21); dan (3) Di dalam Perjanjian Baru, ketentuan dan pelaksanaan

\section{DAFTAR RUJUKAN}

Arief, B. N. (2001). Beberapa Aspek Kebijakan Penegakan Dan Pengembangan Hukum Pidana. Bandung: PT. Citra Aditya Bakty.

Baruch, M. T. (1996). Ucapan Paulus Yang Sulit. Malang: SAAT.

Baruch, M. T. (2010). Ucapan-Ucapan Yesus yang Sulit. Malang: SAAT.

Bergant, D., \& Karris, R. J. (2002). Tafsiran Alkitab Perjanjian Lama. Yogyakarta: Kanisius. hukuman mati, batal dan tidak berlaku lagi, karena Tuhan Yesus Kristus, melalui karya penebusannya (mati di salib, bangkit dari kematian dan akan datang kembali) telah menanggung, memikul dan menyelesaikan masalah dosa, pelanggaran dan kejahatan manusia. Jika selaku masyarakat, bangsa dan negara, dunia hukum dan peradilan, ingin menghormati dan mentaati Allah, firman-Nya dan karyaNya, maka perlu berjuang terus untuk menghapuskan dan meniadakan ketentuan dan pelaksanaan hukuman mati di dunia ini, terutama di Indonesia. Semua ketentuan dan pelaksanaan hukuman mati di dunia ini harus diakhiri dan ditiadakan sama sekali dari bumi milik Tuhan ini, supaya kebenaran, keadilan, kasih dan kebenaran Tuhan boleh terwujud dan membumi di negeri ini. Paling kurang itulah doa, harapan dan perjuangan di dunia hukum dan peradilan Indonesia. Para penegak hukum Kristen, harus berada di garis depan dalam perjuangan ini. Semoga Tuhan menyertai usaha dan perjuangan ini.

Para penegak hukum Kristen di Indonesia, adalah hamba-hamba Tuhan di dunia hukum dan peradilan. Karena itu mereka memiliki peran khusus untuk menegakkan hukum dan keadilan di Indonesia sebagai garam, terang dan ragi dari Kristus bagi persoalan hukum dan pelaksanaannya yang belum berkeadilan. Mereka adalah agen Tuhan yang bertugas memperbaiki dan memperbaharui serta menciptakan ketentuan dan pelaksanaan hukuman mati yang bernilai Alkitabiah-theologis di Indonesia.

Berten, K. (1993). Etika. Jakarta: Gramedia Pustaka Utama.

Brownlee, M. (2015). Pengambilan Keputusan Etis dan Faktor-faktor Di Dalamnya. Jakarta: BPK Gunung Mulia.

Darmawan, I. P. A., \& Asriningsari, A. (2018). Buku Ajar Penulisan Karya Ilmiah. Ungaran: Sekolah Tinggi Teologi Simpson.

End, T. V. D. (2015). Tafsiran Alkitab Surat Roma. Jakarta: BPK Gunung Mulia. 
Geisler, N. 1. (2000). Etika Kristen, Pilihan dan Isu. Malang: SAAT.

Hamzah, A., \& Rahayu, S. (1983). Suatu Tinjauan Ringkas Sistim Pemidanaan di Indonesia. Jakkarta: Akamindo Presindo.

Kansil, C. S. T. (1989). Pengantar Ilmu Hukum dan Tata Hukum Indonesia. Jakarta: Balai Pustaka.

Kitab Undang-undang Hukum Acara Pidana dan Penjelasannya. (1982). Surabaya: Sinar Wijaya.

Lemek, J. (2003, Februari). Setuju Hukuman Mati Terhadap Kejahatan Luar Biasa. Majalah Gloria Edisi 136, 3.

Lubis, T. M. (2005, Januari). Hapuskan Hukuman Mati. Majalah Tempo, 23, 44.

Naiborhu, N. S. (2016). Pandangan Agama Kristen Terhadap Pidana Mati. Jurnal Wawasan Yuridika, 33(2), 141-152. https://doi.org/10.25072/jwy.v33i2.100

Octavianus, P. (2015). Menuju Indonesia Jaya (2005-2030) dan Indonesia Adidaya (20302055). Batu: YPPIB.

Rachman, F. (2018). Implementasi Nilai Pancasila Terhadap Hukuman Mati Tindak Pidana Narkotika. PRANATA HUKUM, 13(2). Diambil dari http://jurnal.ubl.ac.id/index.php/PH/article/v iew/1060

Sahetapy, J. E. (1982). Studi Khusus Mengenai Ancaman pidana Mati Terhadap Pembunuhan Berencana. Jakarta: CV Rajawali.

Saleh, R. (1978). Masalah Pidana Mati. Jakarta: Aksara Baru.

Salmi, A. (1985). Eksistensi Hukuman Mati. Jakarta: Aksara Persada.

Sihombing, L. (2014). Pengantar Etika Kristen. Batu: STT I-3.

Sitompul, A. A. (2015). Manusia dan Kebudayaan, Theologia Anthropologi. Jakarta: BPK Gunung Mulia.
Surjountoro, S. (1974). Kamus Istilah Hukum. Surabaya: PT Bina Ilmu.

Susanto, H. (2019). Gereja sebagai Umat Allah dan Rekan Negara. Jurnal Jaffray, 17(1), 35-56.

Sutoyo, D. (2019). Tinjauan Teologis terhadap Wacana Penerapan Hukuman Mati bagi Pelaku Tindak Pidana Korupsi di Indonesia. DUNAMIS: Jurnal Teologi dan Pendidikan Kristiani, 3(2), 171-198. https://doi.org/10.30648/dun.v3i2.195

Teney, M. C. (1980). The Zondervan Pictorial Encyclopedia Of The Bible. The Zondervan Publishing House.

Tim Penterjemah Badan Pembinaan Hukum Nasionaal Departemen Kehakiman. (1983). KUHP. Jakarta: Sinar Harapan, Anggota IKAPI.

Tjokro, R. (2003, Februari). Prinsip Gereja Menolak Hukuman Mati. Majalah rohani Gloria Edisi 136, 5.

Unger, M. F., \& White, W. (1980). Nelson's Expository Dictionary of the Old Testamen. C. Nashville: Thomas Nelson Publiser.

Verkuyl, J. (2010). Etika Kristen, Ras, Bangsa, Gereja dan Negara. Jakarta: BPK Gunung Mulia.

Verkuyl, J. J. (1997). Etika Kristen Bagian Umum. Jakarta: BPK Gunung Mulia.

White, J. (2015). Kejujuran, Moral dan hati Nurani. Jakarta: BPK Gunung Mulia.

Zainal, M. (1984). Pidana Mati Dihapus atau Dipertahankan. Yogyakarta: Hamindito.

Zaluchu, S. E., \& Gulo, E. K. (2019). (De)Legitimasi Hukuman Pidana Mati: Sebuah Pertimbangan Etis. EPIGRAPHE: Jurnal Teologi Dan Pelayanan Kristiani, $3(1)$, 41-52. https://doi.org/10.33991/epigraphe.v3i1.54 Zodhiates, S. (1996). Hebrew Greek Key Word To Study Bible. Chattanoga: AMG Publisher. 